IRA-International Journal of Management \& Social Sciences

ISSN 2455-2267; Vol.07, Issue 03 (2017)

Pg. no. $458-464$

Institute of Research Advances

http://research-advances.org/index.php/RAJMSS

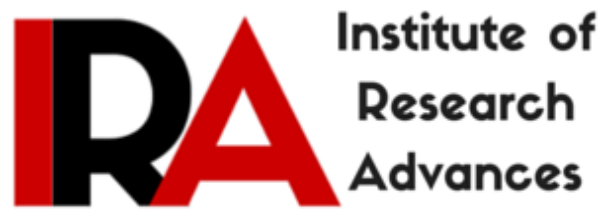

\title{
Socio-Economic Condition of Female Agricultural Labourers- With Special Reference to Mandya District
}

\section{Dr. R. H. Pavithra}

Assistant Professor, Department of Economics, Karnataka State Open University, Mukthagangotri, Mysore 570006, India.

Type of Review: Peer Reviewed.

DOI: http://dx.doi.org/10.21013/jmss.v7.n3.p7

\section{How to cite this paper:}

Pavithra, R. (2017). Socio-Economic Condition of Female Agricultural Labourers- With Special Reference to Mandya District. IRA-International Journal of Management \& Social Sciences (ISSN 2455-2267), 7(3), 458-464. doi:http://dx.doi.org/10.21013/jmss.v7.n3.p7

(C) Institute of Research Advances

\section{(cc) EY-NO}

This work is licensed under a Creative Commons Attribution-Non Commercial 4.0 International License subject to proper citation to the publication source of the work.

Disclaimer: The scholarly papers as reviewed and published by the Institute of Research Advances (IRA) are the views and opinions of their respective authors and are not the views or opinions of the IRA. The IRA disclaims of any harm or loss caused due to the published content to any party. 


\begin{abstract}
Women in rural India are involved in various stages of agricultural operations starting from sowing of seeds to hand weeding, harvesting and post-harvest activities. Over time, as technological change in agriculture has brought about a substantial change in labour-land use pattern, the nature of work of rural women has also undergone a change. Women spend a substantial part of their time not only in various activities directly related to agriculture but also in the management of livestock, poultry, etc. (Sisodia, 1985; Agarwal, 1988). However, the true picture of female work and their contribution to family expenditure is usually not clearly presented. Many economically productive activities performed by women go unrecorded as such or are subsumed within 'domestic work'. In this paper an attempt has been made to study the socio economic condition of female agricultural labourers, and suggest suitable measures for improving their living condition.
\end{abstract}

Key Words: Agriculture, Development, Women, Agricultural Labourers

\title{
Introduction
}

India has a predominantly agrarian economy. $70 \%$ of her population is rural; of those households, $60 \%$ engage in agriculture as their main source of income. It has always been India's most important economic sector. In this important agricultural sector woman plays a vital role, because it is largely a household enterprise. Women in India are major producers of food in terms of value, volume and number of hours worked. Nearly 63 percent of all economically active men are engaged in agriculture as compared to 78 per cent of women. Almost 50 percent of rural female workers are classified as agricultural labourers and $37 \%$ as cultivators. About 70 percent of farm work was performed by women. It is observed that women play a significant and crucial role in agricultural development and allied fields including, main crop production, live-stock production, horticulture, post-harvesting operations, agro/social forestry, fishing etc.; it is a fact long taken for granted but ignored since ages.

The international development community has recognized that agriculture is an engine of growth and poverty reduction in countries where it is the main occupation of the poor. But the agricultural sector in many developing countries is underperforming, in part because women, who represent a crucial resource in agriculture and the rural economy through their roles as farmers, labourers and entrepreneurs, almost everywhere face more severe constraints than men in access to productive resources. Efforts by national governments and the international community to achieve their goals for agricultural development, economic growth and food security will be strengthened and accelerated if they build on the contributions that women make and take steps to alleviate these constraints.

Women make essential contributions to the agricultural and rural economies in all developing countries. Their roles vary considerably between and within regions and are changing rapidly in many parts of the world, where economic and social forces are transforming the agricultural sector. Rural women often manage complex households and pursue multiple livelihood strategies. Their activities typically include producing agricultural crops, tending animals, processing and preparing food, working for wages in agricultural or other rural enterprises, collecting fuel and water, engaging in trade and marketing, caring for family members and maintaining their homes. Many of these activities are not defined as "economically active employment" in national accounts but they are essential to the wellbeing of rural households.

\section{REVIEW OF LITERATURE}

A study by AnuvaSaikia of three villages near Jorhat in the Brahmaputra valley, records that women are engaged in sowing, transplanting, irrigation, hand weeding, harvesting and post-harvest activities. While they perform 80 per cent of transplanting and harvesting, they do not participate at all in spraying insecticides and other pesticides, using tractors and power tillers, or purchasing inputs. For other tasks, women provide 10-30 per cent of the total labour. She notes that this specificity cuts across all farm sizes.

C P Chandra Sekhar and Jayati Ghosh, in "Feminisation of India's Agricultural Workforce" states that the increased involvement of women in agriculture may be due to out migration of males from low paid agriculture to high paid industry. 
The same authors in "Indian Economic Reforms Process and the Implications of South-East Asian Crisis" in 1999, has stated that in India, feminisation in agriculture has been induced by casualisation of work, unprofitable crop production and distress migration. Migration has been noticed to other rural areas, to slums and to highly labour-exploitative sectors of the economy such as construction.

Swarna S Vepa in "Feminisation of Agriculture and Marginalisation of their Economic Stake", Economic and Political Weekly, 2005, proves that increase in women's work in agriculture is due to outmigration of male partners. Women's work remains invisible in family enterprises. Women in rural areas are engaged in other activities (viz., livestock, fisheries and forestry) besides farming. She has calculated that women on an average spend 23.6 hours a week on economic activities, but receive payment for 60 per cent of their work.

\section{Objectives}

1.To analyse the socio-economic condition of female labour force in case study area

2. To suggest suitable measures for the betterment of female labour force.

\section{Methodology}

The present study is on empirical investigation based on sample interview of female agricultural labour force in Mandya district of Karnataka. The present study is based on both secondary and primary data and a systematic random sampling method has been adopted for survey. The primary data has been collected from Mandya district. The sample size comprised of 50 female workers in Mysore district of Karnataka. The present study has selected 25 each from Srirangapatna and Nagamangala( two taluks) respectively in the district for the purpose of primary data collection.

\section{Results and Discussion.}

Table -1 Educational Status of Labourers

\begin{tabular}{|l|l|l|l|}
\hline SI No & Educational level & No of Labourers & Percentage \\
\hline 1 & Illiterate $^{\text {st }}$ to $4^{\text {th }}$ & 25 & 50 \\
\hline 3 & $\mathbf{5}^{\text {th }}$ to $7^{\text {th }}$ & 15 & 30 \\
\hline 4 & Above $7^{\text {th }}$ & 10 & 20 \\
\hline & total & none & 00 \\
\hline
\end{tabular}

\section{Source: Field Survey}

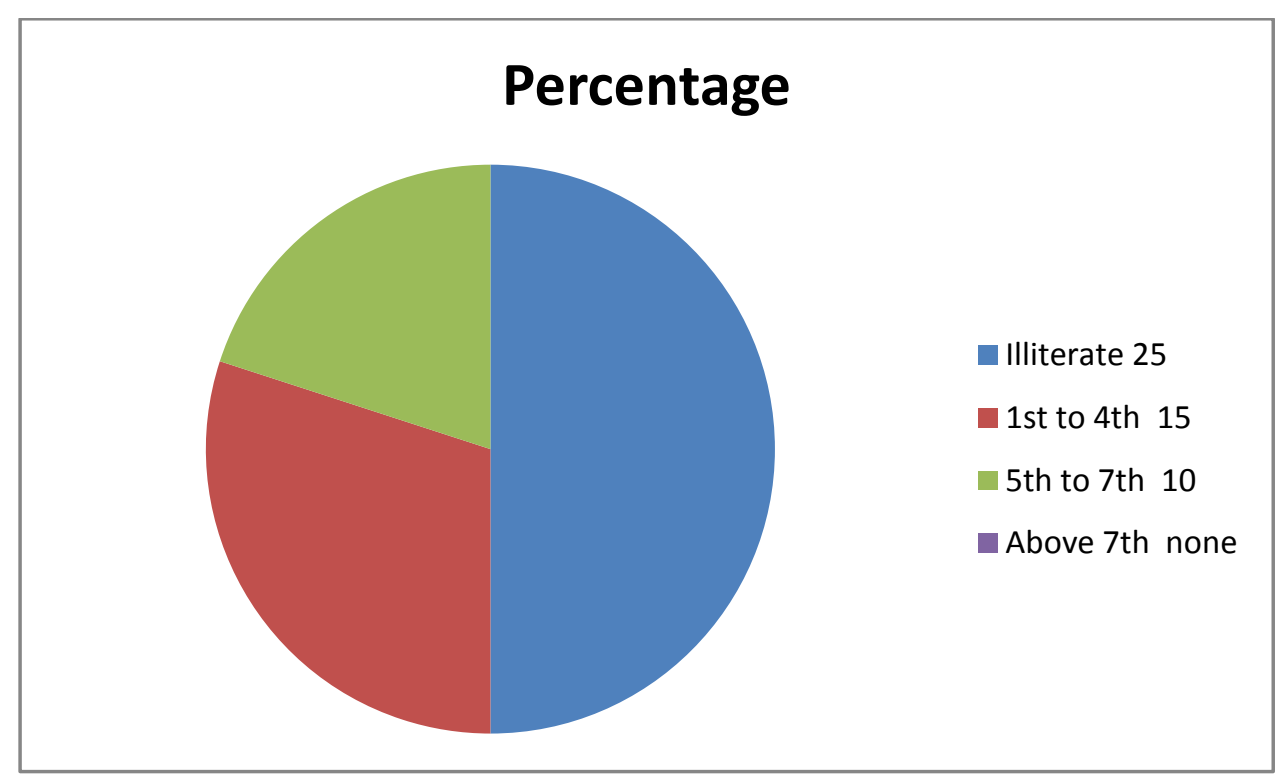


Table 1 states that out of 50 respondents 50 percent of respondents are illiterate followed by 30 percent and 20 percent of the respondents who have studied $1^{\text {st }}$ to $4^{\text {th }}$ standard and $5^{\text {th }}$ to $7^{\text {th }}$ standard respectively. But none among 50 respondents have studied above $7^{\text {th }}$ standard.

Table 2 Access to Potable Drinking Water

\begin{tabular}{|l|l|l|l|}
\hline $\begin{array}{l}\text { Sl } \\
\text { No }\end{array}$ & Access Position & No of Respondents & Percentage \\
\hline 1 & $\begin{array}{l}\text { Access within house } \\
\text { premises }\end{array}$ & 25 & 50 \\
\hline 2 & $\begin{array}{l}\text { Access outside house } \\
\text { premises }\end{array}$ & 25 & 50 \\
\hline & total & 50 & 100 \\
\hline
\end{tabular}

Source: Field Survey

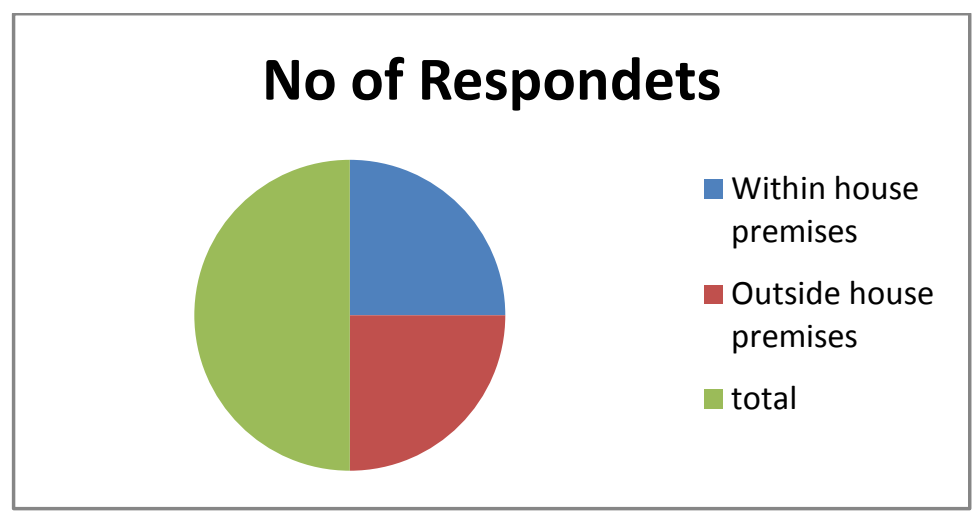

Table 2 states that out of 50 respondents, 25 ( 50 percent) have access to potable drinking water within their house premises, but rest of the 25 (50 percent) have access outside house premises that is that they have to depend on bore wells, street taps, and nearby pond or lake for their day to day activities.

Table 3 Access to Sanitation

\begin{tabular}{|l|l|l|l|}
\hline SI No & Access Position & No of Respondents & percentage \\
\hline 1 & Within house premises & $\mathbf{2 5}$ & $\mathbf{5 0}$ \\
\hline 2 & Outside house premises & $\mathbf{2 5}$ & $\mathbf{5 0}$ \\
\hline & total & $\mathbf{5 0}$ & $\mathbf{1 0 0}$ \\
\hline
\end{tabular}

Source: Field survey

Table 3 reveals that out of 50 respondents 25 (50 percent) have access to sanitation facilities within their house premises but remaining 25 respondents (50 percent) do not have access within their houses, so they have to make use of open ground for their natural calls. 


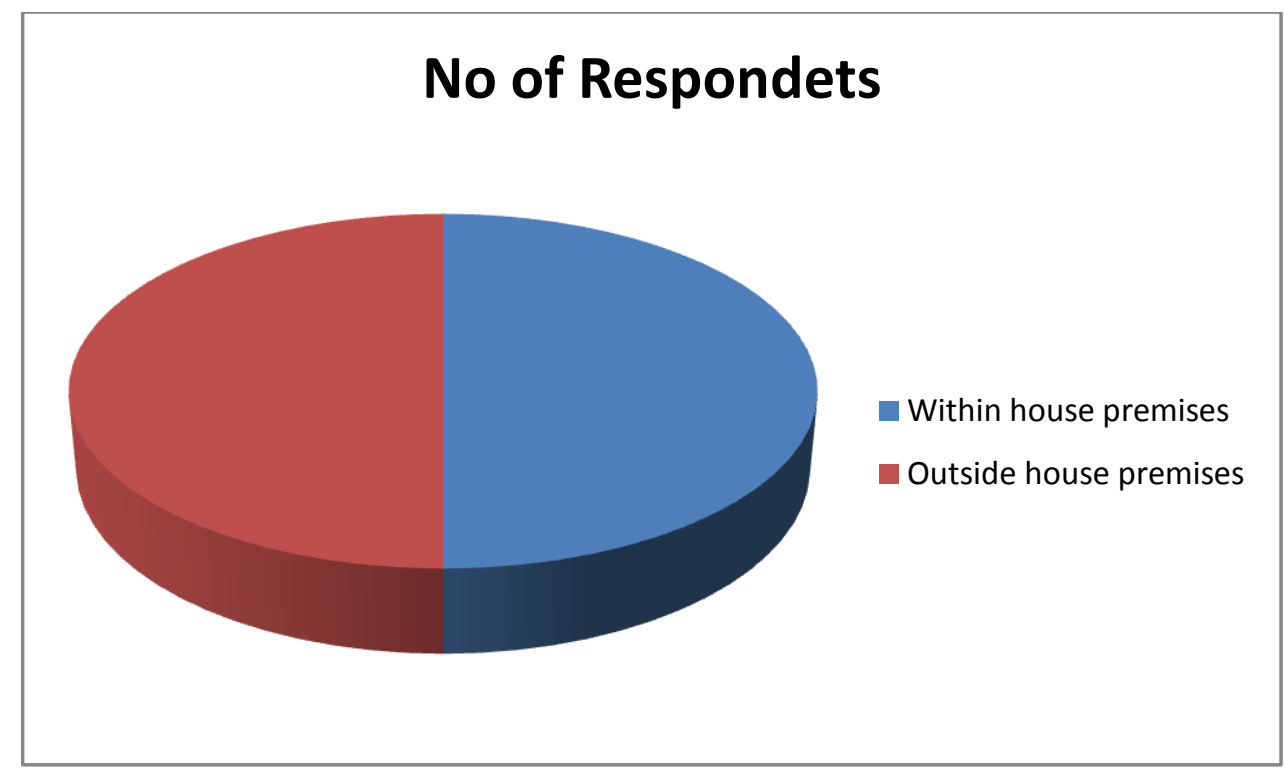

Table 4 Income Level (Monthly)

\begin{tabular}{|l|l|l|l|}
\hline SI No & Income Level (Rs) & No of Respondents & Percentage \\
\hline 1 & 1000 to 2000 & 30 & 60 \\
\hline 2 & 2000 to 5000 & 20 & 40 \\
\hline 3 & Above 5000 & 00 & 00 \\
\hline & total & 50 & 100 \\
\hline
\end{tabular}

Source: Field Survey

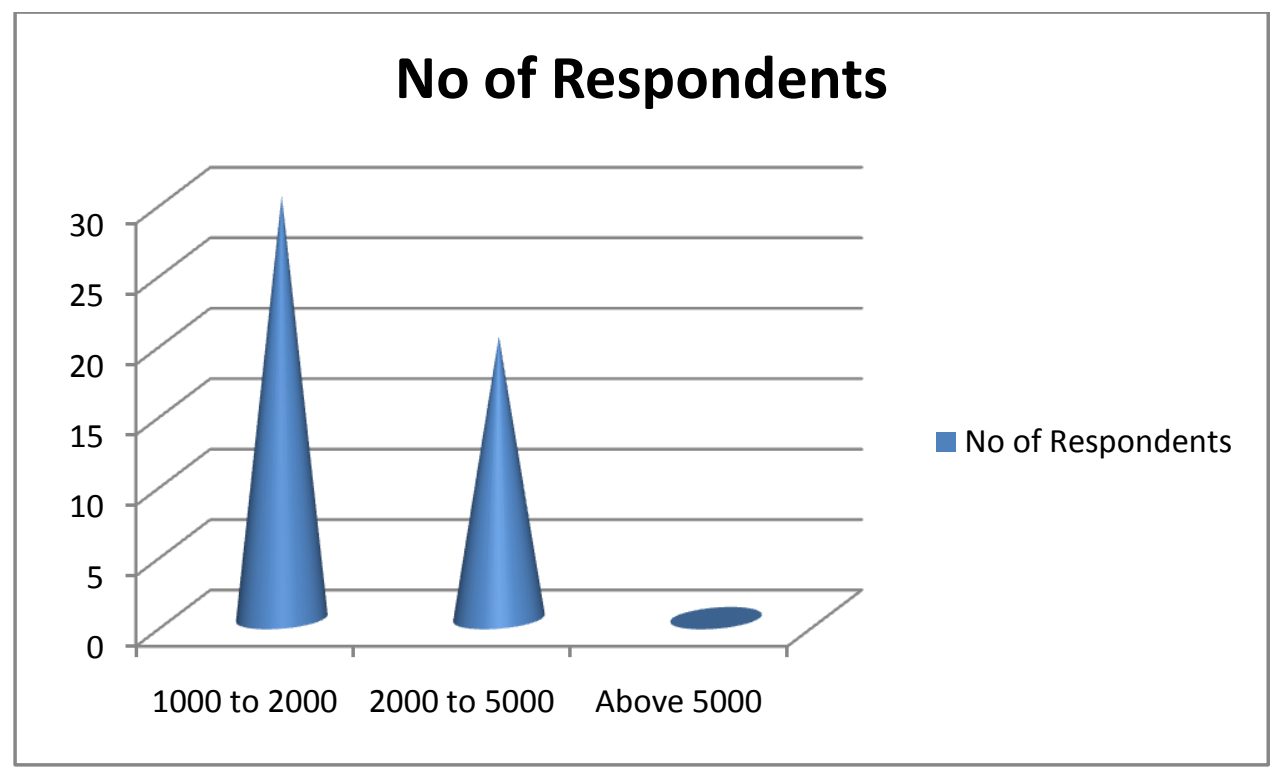

Table 4 states that out of 50 respondents 60 percent of them earn within 1000 to 2000 of income per month, but 40 percent of the earn between 2000 to 5000 Rs as their monthly income. None among 50 respondents have their monthly earnings more than 5000 Rs. 
Table 5 Savings Level (Monthly)

\begin{tabular}{|l|l|l|l|}
\hline SI No & Savings Level (Rs) & No of Respondents & Percentage \\
\hline 1 & No savings & 30 & 60 \\
\hline 2 & Upto 500 & 15 & 30 \\
\hline 3 & $\mathbf{5 0 0}$ to 1500 & 5 & 10 \\
\hline 4 & Above 1500 & 00 & 00 \\
\hline & total & 50 & 100 \\
\hline
\end{tabular}

Sorce: Field Survey

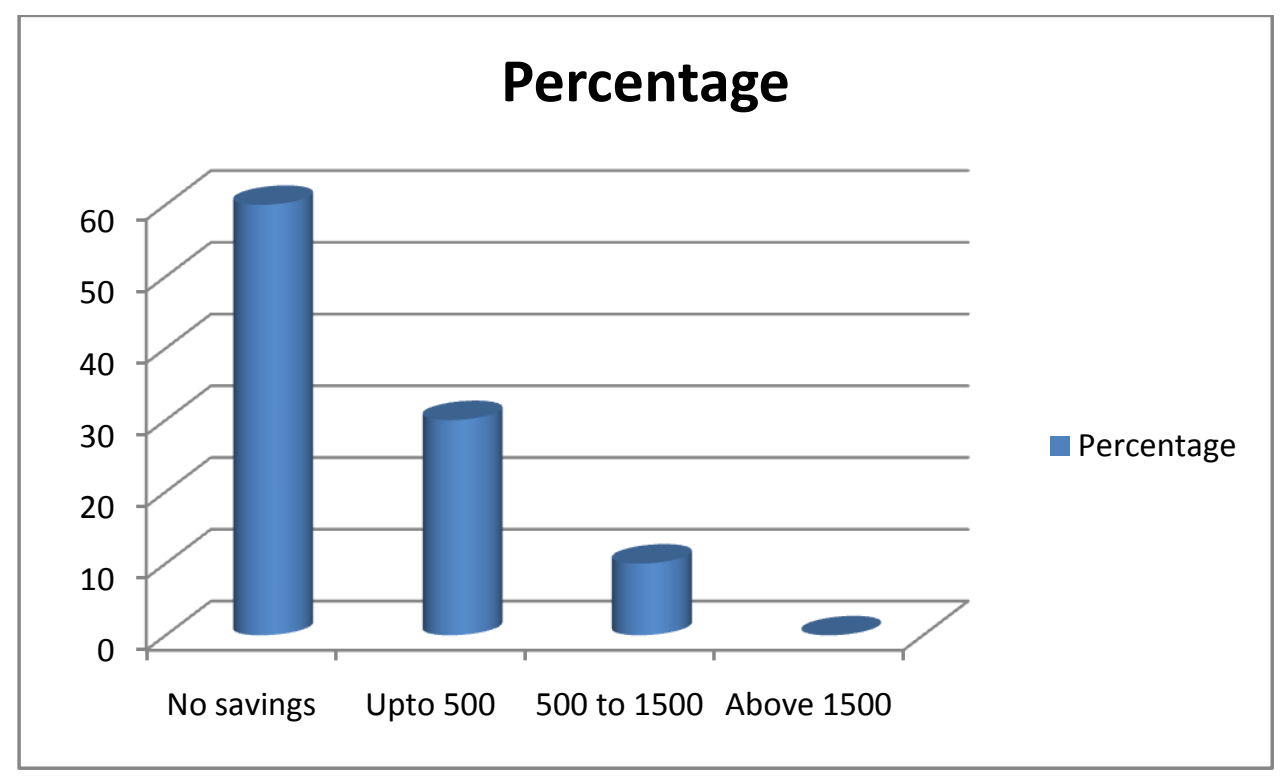

Table 5 states that out of 50 respondents 60 percent have no savings at all, they spend the income earned by them for their day to day activities, hardly 10 percent of respondents save between 500 to 1500 per month and 30 percent of them save very meagre amount up to 500 from their income earned per month.

\section{Findings}

1. Majority of female agricultural labourers are illiterate, it shows that female who have studied beyond SSLC goes for industrial and corporate sector where they get attractive salary.

2. About 50 percent of female agricultural labourers respondents do not have potable drinking water facility within their house premises, thus they have to depend upon bore wells, street taps, nearby pond and lake for their domestic purposes.

3. Again 50 percent of respondents do not have access to sanitation within their houses, and have made them to depend on open ground, which is more unhygienic and hazardous to health.

4. Majority of them (60 percent) of respondents earn between 1000 to 2000 Rs as their monthly income which is not even sufficient for their basic needs, thus large number of female agricultural labourers standard of living condition is very low.

5. Since income of 60 percent of respondents is not sufficient for their basic requirements, obviously their savings will also be nil. It is such a pathetic condition of female labourers to lead their life without savings which is necessary for future unforeseen condition.

\section{Suggestions}

1 Mobile and tent schools have to be started at rural areas, so that education can be provided through such informal mode. At the same time female teachers have to be appointed to teach 
for female children at rural areas so that parents can send their children without fear and restriction.

2. State and local government should provide subsidies to install safe drinking water . facilities within their house premises

3 Regional political leaders have to look into their sanitation facilities of their stipulated area and have to see that their locality is maintained clean and hygiene.

4 Equal remuneration have to be made mandatory rule in order to pay equally in par with men to women in agricultural sector. So that they become economically empowered.

\section{Conclusion}

Female workers contribute significantly to household income and their earnings are crucial especially for landless and marginal farm households. The proportionate contribution of females is, however, found to decline with increasing farm size. This is because the participation rate of women in agriculture is mostly governed by the economic condition of their family. Women from poor families accept any economic work to assist their family even under very inferior working conditions. They are mainly supplementary earners and their stay in labour force is of temporary nature, which declines with the improvement in the economic conditions of the family.

Mandya has a strong tradition of women's involvement in agriculture since ancient times. Gender development is a necessary condition both for economic growth and human development. A new paradigm with women at the core will ensure better participation of men and women and help the society and the economy to grow. Women have the potential to contribute to agricultural productivity equivalent to men. According to an Indian study, development, which provides education and training to women, can enhance the productivity of all farm inputs. Policy makers should not ignore productivity of domestic activity. Improvement in productivity of domestic chores makes it possible for women to spend their time on other income generating activities. If development process emphasizes on the increased income generation through higher agricultural and domestic productivity, benefits would accrue to the community.

\section{References}

1. Agarwal, A.N.(1980), Indian Agriculture, Vikas Publishing House, Uttar Pradesh,

2. Agarwal, Bina (1994): "A Field of One's Own: Gender and Land Rights in South Asia", Cambridge University Press, New Delhi.

3. Desai, Neera and patel, Vibhuti 1985, Women Change and Challenge in the International Decade 1975-85, Popular Prakashan, Bombay,

4. Gulati, Leela, Women in the unorganised Sector with Special Reference to Kerala, In Alakh. N. Sharama and Seema Singh (ed.) 1993, Women and Work, Changing scenario in India, B.R. Publishing Corporation, Delhi,

5. Meenakshi and Ranveer Singh (1995): "Role of Women in Different Systems of Hill Farming: A Study of Himachal Pradesh", Agricultural Economics Research Centre, Shimla.

6. Rao, Nitya (2005): "Gender Equality, Land Rights and Household Food Security", Economic and Political Weekly, June 18.

7. Rustagi, Preet (2003): "Gender Biases and Discrimination against Women: What do Different Indicators Say", CWDS and UNIFEM, New Delhi. 